\title{
Drought occurrences and its implications on the households in Yobe state, Nigeria
}

\author{
Jude Nwafor Eze(1)
}

\begin{abstract}
The study assesses the extent of droughts and its implications on the households in the study area. This is to highlight the need to integrate drought adaptation options into the government development plans. Strategies for drought adaptation options in the study area have often been made without experimental foundations placed on the extent of drought and its implications on the households. To achieve this, the study employed Normalized Rainfall Index (NRI) to determine the extent of droughts and its implications on the households, which has much to offer in terms of policy decisions. The study also utilized questionnaire administrated to 400 households to determine the annual income from different occupations that yielded more income to the people in the study area using one-way analysis of variance (ANOVA). The NRI shows that the study area was characterized by mild to severe drought events. The first (1986-1995) and third (2006-2017) decades experienced high incidences of droughts, while the second decade (1996-2005), witnessed the least incidences of droughts. The result of the economic activities of the households reveals that $65 \%$ of the total household respondents were involved in farming, while $35 \%$ were involved in non-farming activities as their major source of livelihood. The analysis of variance on the economic activities that generated more income to the households in Yobe State shows that farming activities provided more opportunities for income generation. Consequently, agriculture in the study area is currently being constrained by the frequent occurrence of droughts. Thus, there is a need for integrated development schemes aimed at livelihood diversification and increasing the adaptive capacity of households to drought in the study area.
\end{abstract}

Keywords: Drought, Desertification, Vulnerability, Normalized rainfall index

\section{Background}

Drought is one of the most globally recognized hazards that damage an environment. It occurs when there is significant rainfall deficit that causes hydrological imbalances and affects the land productive systems. Drought practically occurs in all climatic regions with both high and low mean rainfalls (Um et al. 2017). It can result in damage to agricultural production as well as to the natural environment and human society (Gidey et al. 2018). Drought is considered to be a natural disaster that differs from other natural disasters because it has a gradual creeping feature (Ayoade 1988; Yue et al. 2018). Liu et al., (2018) opine that drought develops slowly with prolonged effects that gradually increases in severity and tends to persist over a long period of time even after it has stopped. Analysis of the orbital photographs from

Correspondence: zejude12@gmail.com

Farming System Research Programme, National Cereals Research Institute, Badeggi P.M.B 8, Bida, Niger State, Nigeria
National Aeronautics and Space Administration (NASA) shows that about $900,000 \mathrm{~km} 2$ of former savanna grassland in the region of Africa has been severely decertified between the early 1960s and 1986 due to persistent drought occurrences (O'Connor 1995). Moreover, Bates et al. (2008) state that one-third of African population lives in drought-prone areas. The drought has become a recurrent event in many parts of Africa, after the drought of the early 1970s that devastated the Sahel region. Dai et al. (2004) have shown that there is about $40 \%$ decline in annual rainfall total in West Africa, from the year 1968-1990 as compared with the 30 years between 1931 and 1960. Thus, frequent drought occurrences are threatening the human existence in African savanna regions and consequently making the households highly vulnerable to drought.

In Northern Nigeria, there are several records of drought occurrences which resulted in famines, such as the droughts of 1903 and 1911-1914 (Shiru et al. 2018). 
Other droughts occurred in 1919, 1924, 1935 (Tarhule and Woo 1997), 1951-1954, 1972-1973, 1984-1985 (Mortimore 1989), 2007 and 2011 (Abaje et al. 2013). Consequently, the situation is being exacerbated by the increasing human population, overgrazing, over-cultivation, and high poverty rate (Eze 2017). The predominant economic activity in the region is farming. Moreover, the region is known for its grain products such as maize, millet, sorghum, and wheat (Eze 2017). Agricultural production in Nigeria particularly in Northern Nigeria is mainly rain-fed and naturally prone to vagaries of rainfall variability (Tiamiyu et al. 2015). During the years of abundant rainfall, households in the region experience bumper harvest from both crop and livestock productions. Conversely, during the years with rainfall deficit, the households experience crop failure, poor crop yield, leading to famine, hunger, and death, including livestock (Eze et al. 2018). Khalil (1974) shows that about 300, 000 livestock died during the drought that occurred in the year 1972 to 1973 . The number of livestock that died during this period represents about $13 \%$ of the total livestock population in the north-eastern part of Nigeria (Khalil 1974). Moreover, in the year 1987, towards the end of the growing season, huge crop losses to drought were recorded in many parts of northern Nigeria, particularly, in the Sahel region (Mortimore 1989).

Studies on the impact of drought have been undertaken in various parts of the world (Oladipo 1993; Obaje et al., 2013; Wu et al., 2015a, 2015b; Olagunju 2015; Hosseinizadeh et al. 2015; Um et al. 2017; LIU et al. 2018; Yue et al. 2018). Majority of the studies concentrated on the impact of drought on agriculture, health, water resources, causes and effects on the land, mitigation and the extent of drought. Little or no work has been done in the study area to determine quantitatively drought occurrences and its implications on the households using Normalized Rainfall Index (NRI), which has much to offer in terms of policy decisions. Oladipo (1993) argues that the degree of impact of a particular drought on the environment and the extent to which it may affect the households depends on the length of the period separating the drought event from the previous one. Moreover, Abaje et al. (2013) state that there is a need for appropriate techniques to be used to determine drought occurrence so as to reduce its impact on the environment. Against this background, the research seek to determine quantitatively the drought occurrences and its implications on the households, in order to provide the basis for the design and mainstreaming of drought adaptation into the development process in the study area.

\section{Materials and methods}

\section{Study area}

Yobe State is on latitudes $10^{\circ} 30^{\prime} \mathrm{N}$ to $13^{\circ} 25^{\prime} \mathrm{N}$ and longitudes $9^{\circ} 35^{\prime} \mathrm{E}$ and $12^{\circ} 30^{\prime} \mathrm{E}$. It is bounded by the Nigerian
States of Gombe to the southwest, Bauchi to the west, Jigawa to the northwest, Borno to the east, and to the North by the Niger Republic. The study area has a population of 2,532,395, according to 2006 census, and a land mass of $47,153 \mathrm{~km}^{2}$. The density is thus 29.92 persons per square kilometre.

The climate regime of the study area is characterized by single long dry season followed by a shorter wet season. In the Sahel, mean annual rainfall is less than $500 \mathrm{~mm}$ and may fall to $250 \mathrm{~mm}$ (Ayoade 1988). In the Sudan savanna, it is $800 \mathrm{~mm}$ to $1000 \mathrm{~mm}$. The number of wet months is about 4 months in the northern guinea savanna zone to less than 2 months in the Sahel savanna zone (Folland et al., 1986; Anyadike, 1993). Mean annual temperature is $260 \mathrm{C}$ increasing towards the Sahel zone. Potential evapo-transpiration exceeds rainfall except for the few months. Vegetation of the study area is divided into the Wooded Tropical savanna, Mixed combrataceous woodland and wooded savannah. The Wooded tropical savanna also known as Sahel savanna is found in the northern part of the state, where rainfall is less than $500 \mathrm{~mm}$ per annum. The vegetation consists of thorn bushes and small trees which grow under dry conditions. Mixed combrataceous woodland covers the central part of the study area. It has more rainfall than the wooded tropical savanna and it consists of scrub vegetation interspersed with tall trees (Nwaka, 1991). The wooded savanna covers most of the southern part of the state, with a higher grass growth. It is also known as northern guinea savanna. The main trees are the isoberlina species. Administratively, there are seventeen Local Government Areas (LGAs) in Yobe State. The semi-arid zone in the study comprises of the Sudan and the Sahel regions, which by its nature and characteristics are susceptible to drought and desertification. These zones are most vulnerable to drought and desertification because the predominant economic activity of the people in the communities is farming (Musa and Shaib 2010).

\section{Study design}

The study adopted the survey design. The study population consists of 443,375 households in Yobe State (National Population Commission 2006). Out of this number, 400 households were proportionally selected and interviewed based on the relative population of each of the 17 LGAs using Yamane (1967) sample size selection method (Table 1).

The data utilized for this study were obtained from primary and secondary sources. The primary data were obtained through an administered questionnaire and in-depth interviews. Purposive sampling technique was employed to select the key informants and communities studied while the simple random sampling technique was employed to select the households. Ten key 
Table 1 Sample Size of the Household Respondents in the Study Area

\begin{tabular}{lll}
\hline $\begin{array}{l}\text { Local Govt } \\
\text { Area }\end{array}$ & $\begin{array}{l}\text { Number of Households } \\
\text { per LGAs }\end{array}$ & $\begin{array}{l}\text { Sample Size of Respondents } \\
\text { per LGA }\end{array}$ \\
\hline Bade & 26,193 & 24 \\
Busari & 21,435 & 19 \\
Damaturu & 17,212 & 15 \\
Fika & 24,622 & 23 \\
Fune & 52,489 & 52 \\
Geidam & 31,243 & 27 \\
Gujba & 22,430 & 22 \\
Gulani & 20,396 & 18 \\
Jakusko & 43,585 & 39 \\
Karasuwa & 20,752 & 18 \\
Machina & 12,583 & 11 \\
Nangere & 15,807 & 17 \\
Nguru & 29,200 & 26 \\
Potiskum & 36,341 & 35 \\
Tarmuwa & 16,394 & 13 \\
Yunusari & 27,478 & 22 \\
Yusufari & 25,215 & 19 \\
Total & 443,375 & 400 \\
\hline Source: Nato & & \\
\hline
\end{tabular}

Source: National Population Commission

informants were selected for in-depth interviews in each LGA giving a total of 170 respondents. The secondary data utilized were climatic data on rainfall, from 1986 to 2017.

\section{Data analysis}

The data collected were analysed using descriptive statistics (standard deviation, the coefficient of variation, skewness and kurtosis), percentages and Analysis of Variance (ANOVA). Normality of the annual rainfall series for Nguru, Potiskum, and Maiduguri was tested using the standardized coefficients of Skewness (Z1) and Kurtosis (Z2) statistics as defined by Brazel and Balling (1986). The standardized coefficient of Skewness (Z1) was calculated as:

$$
Z_{1}=\left\lceil\left\{\underset{i-1}{N}(x i-\bar{x})^{3 / N}\right\} /\left\{\begin{array}{c}
N \\
z \\
i-1
\end{array}(X i-\bar{x})^{2 / N}\right\} \quad 7 /(6 / N)^{1 / 3}\right.
$$

However, the standardized coefficient of Kurtosis (Z2) was determined as

$$
\left.Z_{2}=\left\lceil\left\{\underset{i-1}{N}(x i-\bar{x})^{4 / N}\right\} /\{\underset{i-1}{N} \underset{i}{z}(X i-\bar{x}))^{2 / N}\right\}{ }^{2}\right]-3 /(24 / N)^{1 / 2}
$$

Where $\overline{\mathrm{x}}$ is the long term mean of $\mathrm{x}_{\mathrm{i}}$ values and $N$ is the number of years in the sample. These statistics were used to test the null hypothesis that the individual temporal samples came from a population with a normal
(Gaussian) distribution. If the absolute value of $\mathrm{Z}_{1}$ or $\mathrm{Z}_{2}$ is greater than 1.96, a significant deviation from the normal curve is indicated at the 95\% confidence level.

Normalized Rainfall Index (NRI), as defined by Türkes (1996) was used to show periods of different drought intensities in the study area. This index uses annual rainfall totals and the standard deviation to indicate the shortage of rainfall in any given year. The Index for a given station was computed for each year from 1986 to 2017 (Table 4). The Annual rainfall amount $\left(\boldsymbol{R}_{\boldsymbol{t s y}}\right)$ expressed in millimeters, Long term mean $\left(\boldsymbol{L}_{\boldsymbol{t} m}\right)$ and the Standard deviation $\left(\boldsymbol{S}_{\boldsymbol{t} \boldsymbol{d}}\right)$ as recorded in Table 3 has been used in calculating the NRI. The classification was based on Türkes (1996) modified version of classification of normalized rainfall index.

$\mathbf{N R I}=\left(\mathbf{R}_{\mathbf{t s y}}-\mathbf{L}_{t m}\right) / \mathbf{S}_{t d}(3)$

Where $R_{\text {tsy }}=$ the rainfall total for the station during a year (or season).

$\mathrm{L}_{\mathrm{tm}}=$ the long term mean (of the period specified for the station) and.

$\mathrm{S}_{\mathrm{td}}=$ Standard deviation of the annual (or seasonal) rainfall total for that station.

The Table 2 below is the Türkes (1996) modified version of the normalized rainfall index classification. In this very study, the modified classification of NRI was adopted.

Data on the annual income from the different occupation of the respondents were collected to determine the occupation that yielded more income to the people in the study area using one-way analysis of variance (ANOVA). Hypotheses $\left(\mathrm{H}_{\mathrm{o}}\right.$ and $\left.\mathrm{H}_{1}\right)$ therefore, were formulated and tested as shown below.

Hypotheses for the income generated from various occupation

$\mathbf{H}_{\mathbf{0}}$ : There is no significant difference in income generated from the various occupation of the study population in the study area.

$\mathbf{H}_{\mathbf{1}}$ : There is significant difference in income generated from the various occupation of the study population in the study area.

Table 2 Modified Classes of NRI Values

\begin{tabular}{lll}
\hline Index & Character of Rainfall & Vulnerability level \\
\hline 1.31 or more & Very wet & Highly vulnerable \\
0.86 to 1.30 & Moderately wet & Vulnerable \\
0.51 to 0.85 & Mildly wet & Slightly vulnerable \\
0.50 to -0.50 & Near normal & Not vulnerable \\
-0.51 to -0.85 & Mild drought & Slightly vulnerable \\
-0.86 to -1.30 & Moderate drought & Vulnerable \\
-1.31 or less & Severe drought & Highly vulnerable
\end{tabular}

Source: Adapted from Turkes (1996) 
Table 3 Summarized rainfall statistics for the study area (Maiduguri, Nguru and Potiskum stations)

\begin{tabular}{llllllll}
\hline Stations & Number of Years & Total amount of Rainfall & Long term Mean & Std deviation & Variance & Skewness & Kurtosis \\
\hline Maiduguri & 31 & 1554.60 & 50.15 & 11.47 & 131.64 & 0.63 & 0.16 \\
Nguru & 31 & 1082.90 & 34.93 & 6.34 & 40.19 & 0.52 & -0.87 \\
Potiskum & 31 & 1700.20 & 54.85 & 8.30 & 68.81 & -1.01 & 1.15 \\
\hline
\end{tabular}

Source: Computed by the author

\section{Results}

\section{Tests for normality of rainfall in the study area}

The results of the coefficient of Skewness and Kurtosis both show that rainfall series had no significant deviation from the normal curve (1.96) at 95\% confidence level. Therefore, the rainfall sequence was normally distributed. The Standard Deviation (Std) decreased below the Meanwhile the Coefficient of Variation (CV) was considerable (Table 3).

\section{Normalized rainfall index (NRI)}

NRI $=($ Rtsy $-\mathrm{Ltm}) /$ Std for Potiskum station for $1986=$ $811.4-720 / 100.2=0.91$.

Table 4 Computation of Normalized Rainfall Index (NRI) for the study area (Maiduguri, Nguru and Potiskum Stations)

\begin{tabular}{|c|c|c|c|c|c|c|}
\hline Years & NRI for Potiskum & Character of rainfall & NRI for Nguru & Character of rainfall & NRI for Maiduguri & Character of rainfall \\
\hline 1986 & 0.91 & Moderately wet & -0.41 & Near normal & -0.49 & Near normal \\
\hline 1987 & -1.36 & Severe drought & -2.11 & Severe drought & -1.92 & Severe drought \\
\hline 1988 & 0.38 & Near normal & 0.14 & Near normal & 0.45 & Near normal \\
\hline 1989 & 2.05 & Very wet & -2.27 & Severe drought & 0.36 & Near normal \\
\hline 1990 & -0.37 & Near normal & 0.15 & Near normal & -2.81 & Severe drought \\
\hline 1991 & -1.17 & Moderate drought & -1.72 & Severe drought & -1.77 & Severe drought \\
\hline 1992 & -1.18 & Moderate drought & 0.54 & Mildly wet & -0.2 & Near normal \\
\hline 1993 & -1.45 & Severe drought & -2.21 & Severe drought & -1.63 & Severe drought \\
\hline 1994 & 0.68 & Mildly wet & 2.78 & Very wet & -2.26 & Severe drought \\
\hline 1995 & -1.15 & Moderate drought & -0.77 & Mild drought & 0.90 & Moderately wet \\
\hline 1996 & 0.26 & Near normal & 0.99 & Moderately wet & 0.39 & Near normal \\
\hline 1997 & 0.29 & Near normal & 1.58 & Very wet & -0.90 & Moderate drought \\
\hline 1998 & 1.02 & Moderately wet & 0.72 & Mildly wet & 0.98 & Moderately wet \\
\hline 1999 & 0.24 & Near normal & 0.39 & Near normal & 2.08 & Very wet \\
\hline 2000 & -1.65 & Severe drought & -1.6 & Severe drought & 0.86 & Moderately wet \\
\hline 2001 & 0.55 & Mildly wet & -0.45 & Near normal & 1.39 & Very wet \\
\hline 2002 & -0.29 & Near normal & 0.58 & Mildly wet & -2.64 & Severe drought \\
\hline 2003 & 0.22 & Near normal & 1.01 & Moderately wet & 0.59 & Mildly wet \\
\hline 2004 & -2.16 & Severe drought & -2.84 & Severe drought & 0.42 & Near normal \\
\hline 2005 & 0.47 & Near normal & 0.56 & Mildly wet & 3.18 & Very wet \\
\hline 2006 & -0.91 & Moderate drought & -0.14 & Near normal & -0.75 & Mild drought \\
\hline 2007 & -0.48 & Near normal & 0.83 & Mildly wet & 1.42 & Very wet \\
\hline 2008 & 1.02 & Moderately wet & -1.94 & Severe drought & -0.44 & Near normal \\
\hline 2009 & -0.54 & Mild drought & -1.02 & Moderate drought & -0.25 & Near normal \\
\hline 2010 & -1.53 & Severe drought & 0.88 & Moderately wet & -3.38 & Severe drought \\
\hline 2011 & -0.53 & Mild drought & -0.98 & Moderate drought & 0.35 & Near normal \\
\hline 2012 & 1.02 & Moderately wet & 0.87 & Moderately wet & 1.10 & Moderately wet \\
\hline 2013 & -0.13 & Near normal & -0.63 & Mild drought & -1.47 & Severe drought \\
\hline 2014 & 0.90 & Moderately wet & 0.61 & Mildly wet & -0.19 & Near normal \\
\hline 2015 & -0.33 & Near normal & -1.21 & Moderate drought & -0.57 & Mild drought \\
\hline 2016 & 0.57 & Mildly wet & 0.69 & Mildly wet & 0.53 & Mildly wet \\
\hline 2017 & -1.27 & Moderate drought & -0.97 & Moderate drought & -1.19 & Moderate drought \\
\hline
\end{tabular}

Source: Computed by the Author using Microsoft Excel 


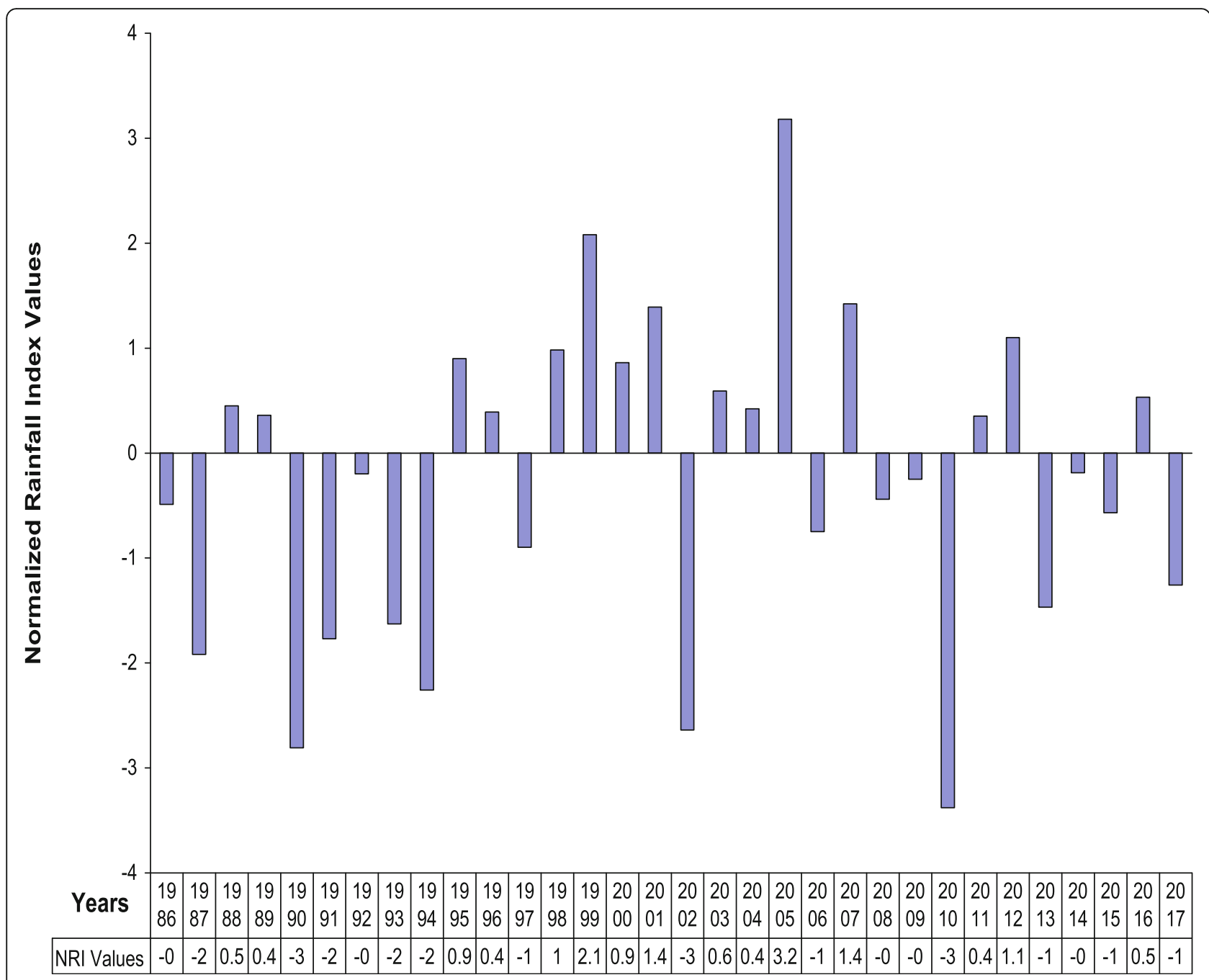

Fig. 1 Normalized rainfall index for Maiduguri station (Data source: Nigerian Meteorological Agency Abuja)

The NRI calculations for the rest of the stations per year followed the same procedure. The results are shown in Table 4.

\section{The incidence of droughts in the study area}

The results on the Normalized Rainfall Index analysis in the study area are also presented graphically in Figs. (13) for Maiduguri, Nguru and Potiskum stations. The results show that the study area experiences mild to severe drought events. Severe drought conditions occurred in the northeastern and central parts of the study area (Maiduguri station) in 1987, 1990, 1991, 1993, 1994, 2002, 2010 and 2013 with a moderate drought that occurred in 1997 and 2017, including mild droughts of 2006 and 2015 (Fig. 1). In the Northwestern part of the study area (Nguru station), severe droughts occurred in 1987, 1989, 1991, 1993, 2000, 2004 and 2008 with moderate droughts in 2009, 2011, 2015 and 2017 and also mild droughts in 1995 and 2013 (Fig. 2). In the southern parts of the study area (Potiskum station), severe droughts occurred in 1987, 1993, 2000 and 2010, with moderate droughts that occurred in 1991, 1992, 1995, 2006 and 2017, while mild droughts occurred in 2009 and 2011(Fig. 3).

\section{Economic activities of the households in the study area}

The survey on the economic activities of the households reveals that the study population is involved in five major economic activities that influence their livelihood security (Table 5). The result shows that $65 \%$ of the total household respondents were involved in farming as their major source of livelihood. However, $35 \%$ of the total population was involved in non-farming activities such as trading (15\%), civil service (11\%), artisan $(6 \%)$ and fishing (3\%). Table 5 also shows the percentage variations in household respondents involved in different economic activities in the seventeen LGAs in the study area. The result shows that Bade, Damaturu, Nguru, 


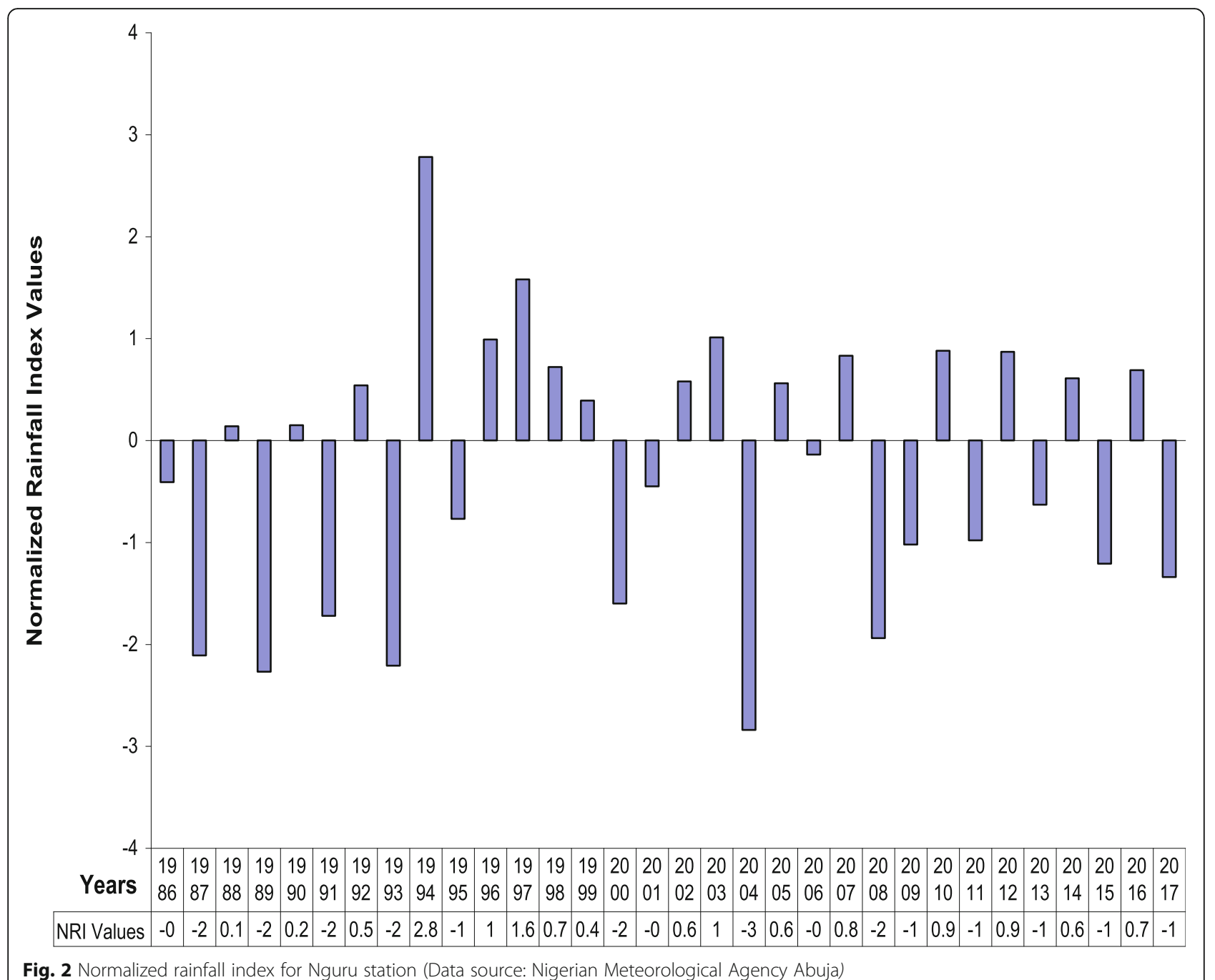

Potiskum, Fika, Gujba and Gulani have 56\%, 77\%, 81\%, $71 \%, 44 \%, 46 \%, 49 \%$ of the total household respondents that were engaged in non-farming activities respectively. Moreover, Karasuwa, Jakusko, Machina, Yunusari, Yusufari, Busari, Fune, Nangere, Geidam and Tarmuwa have $28 \%, 26 \%, 27 \%, 27 \%, 21 \%, 27 \%, 28 \%, 30 \%, 30 \%$ and $28 \%$ of the total household respondents that were engaged in non-farming activities respectively.

\section{Income status of the respondents in relation to their economic activities}

The result on the mean annual income of the respondents generated from five different occupations was farming (N121, 450), Trading (N58, 741), Civil service (N33, 000), Fishing (N28, 064) and Artisan (N28, 737) (Table 6). However, the analysis of variance to determine which occupation that yielded more income to the people of Yobe State produced an F-ratio of 13.77 and $p$-value of .00001 (Table 7). Since the calculated F-ratio is greater than p-value at 0.05 level of significance, Ho was rejected and $\mathrm{H} 1$ was accepted. Thus, there is a statistically significant difference in the income of the respondents from different occupations in the study area. This implies that occupation with higher mean income level provides more opportunities to the people for income generation.

\section{Discussion}

The impact of droughts on the environment and human comfort in the study area

The incidences of drought in the study area indicate that, out of 32 years under study, only 12 years were free from drought. The first (1986-1995) and third (20062017) decades experienced very high incidences of droughts, particularly mild to severe droughts, thus making the decades the driest period. However, the second decade (1996-2005), witnessed the least incidences of droughts, thus making the period relatively wet 


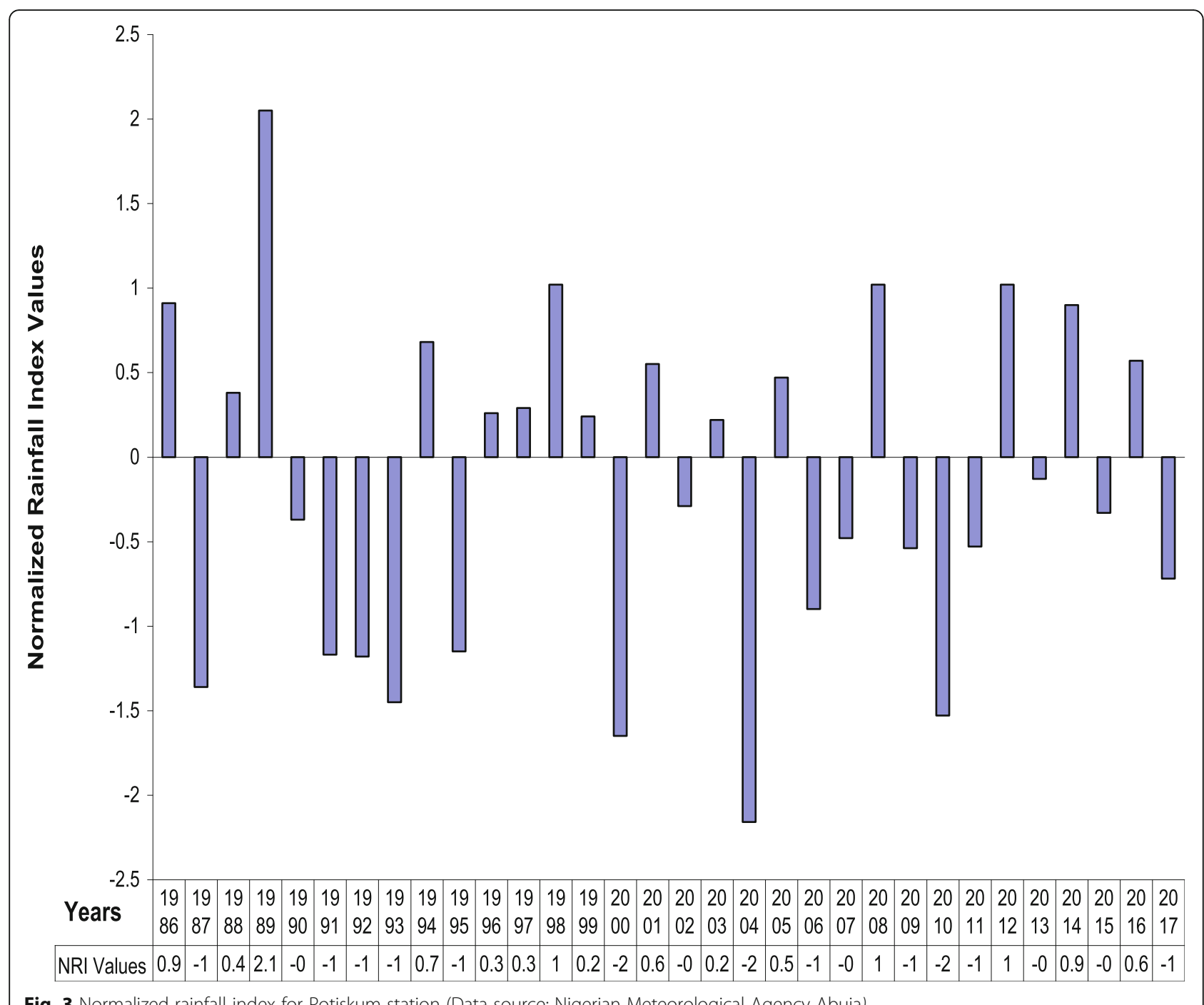

Fig. 3 Normalized rainfall index for Potiskum station (Data source: Nigerian Meteorological Agency Abuja)

compared to other decades. Some of the droughts that occurred during the period of study were localized, while other incidences of droughts affected the entire study area with serious negative consequences on the vital life support systems (rivers, wetlands and rangelands) that provide means of livelihood to the households.

However, the researcher observed that the respondents were predominantly involved in 5 major economic activities. The greater percentage of the total respondents was engaged in farming activities (65\%) than non-farming activities (35\%) for the purpose of generating income which was used to enhance their livelihood. The study observed that most respondents from other employment such as trading, civil service, artisan and fishing activities were also involved in farming. Moreover, the analysis of variance on the economic activities that generated more income to the households in the study area shows that farming activities provided more opportunities for income generation. Apart from trading with few manufactured goods, most of the industries in the study area use the raw materials sourced locally especially from farm produce. Therefore, the livelihood of the households living in the study area predominantly depends on agriculture. Consequently, poor regions of the world, such as Africa, which depends on agriculture, have been described as one of the most vulnerable regions to the impacts of climatic and environmental changes, particularly drought, desertification and flood (Reid and Vogel 2008, Tschakert 2007). Thus, in-depth interviews with the key informants show that water scarcity due to the occurrence of droughts affects the agricultural outputs in the study area. There were food shortages resulting from an abnormal reduction in crop yield due to droughts. Irrigation projects which would have served to mitigate these problems were also affected by water shortages as most of the dams dried up 
Table 5 Major economic activities of the respondents in the study area

\begin{tabular}{llllll}
\hline LGA's & Farming & Trading & Civil Service & Artisan & Fishing \\
\hline Bade & $11(44 \%)$ & $5(22 \%)$ & $2(8 \%)$ & $4(16 \%)$ & $2(10 \%)$ \\
Busari & $14(73 \%)$ & $2(12 \%)$ & $1(4 \%)$ & $1(5 \%)$ & $1(6 \%)$ \\
Damaturu & $4(23 \%)$ & $3(20 \%)$ & $6(40 \%)$ & $2(17 \%)$ & $0(0 \%)$ \\
Fika & $13(56 \%)$ & $6(26 \%)$ & $2(10 \%)$ & $2(8 \%)$ & $0(0 \%)$ \\
Fune & $37(72 \%)$ & $4(8 \%)$ & $3(6 \%)$ & $5(10 \%)$ & $2(4 \%)$ \\
Geidam & $19(70 \%)$ & $3(12 \%)$ & $1(5 \%)$ & $1(4 \%)$ & $2(9 \%)$ \\
Gujba & $12(54 \%)$ & $3(15 \%)$ & $3(13 \%)$ & $2(7 \%)$ & $2(11 \%)$ \\
Gulani & $9(51 \%)$ & $5(23 \%)$ & $2(12 \%)$ & $1(8 \%)$ & $1(6 \%)$ \\
Jakusko & $29(74 \%)$ & $4(10 \%)$ & $3(8 \%)$ & $2(5 \%)$ & $1(3 \%)$ \\
Karasuwa & $13(72 \%)$ & $3(15 \%)$ & $1(7 \%)$ & $1(6 \%)$ & $0(0 \%)$ \\
Machina & $8(73 \%)$ & $1(10 \%)$ & $1(9 \%)$ & $1(8 \%)$ & $0(0 \%)$ \\
Nangere & $12(70 \%)$ & $3(18 \%)$ & $2(7 \%)$ & $1(5 \%)$ & $0(0 \%)$ \\
Nguru & $5(19 \%)$ & $9(35 \%)$ & $6(23 \%)$ & $4(15 \%)$ & $2(8 \%)$ \\
Potiskum & $10(29 \%)$ & $15(43 \%)$ & $6(17 \%)$ & $4(11 \%)$ & $0(0 \%)$ \\
Tarmuwa & $9(72 \%)$ & $1(9 \%)$ & $2(12 \%)$ & $1(5 \%)$ & $0(2 \%)$ \\
Yunusari & $16(73 \%)$ & $2(9 \%)$ & $2(8 \%)$ & $1(4 \%)$ & $1(5 \%)$ \\
Yusufari & $15(79 \%)$ & $2(10 \%)$ & $1(5 \%)$ & $0(6 \%)$ & $0(0 \%)$ \\
Total & 260 & 59 & 44 & 24 & 13 \\
\% & 65 & 15 & 11 & 6 & 3 \\
\hline Source: & & & &
\end{tabular}

Source: Fieldwork 2017

Table 6 Annual Income of the Respondents from different Occupations

\begin{tabular}{llllll}
\hline LGA's & Farming & Trading & Civil service & Fishing & Artisan \\
\hline Bade & 111,650 & 56,000 & 34,000 & 29,564 & 37,135 \\
Busari & 53,770 & 27,250 & 25,000 & 30,560 & 27,000 \\
Damaturu & 85,670 & 167,450 & 51,000 & & 46,553 \\
Fika & 149,450 & 45,325 & 30,000 & & 26,972 \\
Fune & 119,630 & 32,745 & 26,000 & & 21,126 \\
Geidam & 79,820 & 27,000 & 27,000 & 32,675 & 23,000 \\
Gujba & 193,240 & 69,000 & 36,000 & 24,530 & 31,704 \\
Gulani & 188,467 & 57,000 & 32,000 & 28,225 & 30,567 \\
Jakusko & 75,550 & 26,125 & 26,000 & & 17,500 \\
Karasuwa & 69,450 & 36,000 & 28,000 & & 19,350 \\
Machina & 82,650 & 31,000 & 31,000 & & 21,235 \\
Nangere & 128,725 & 34,000 & 34,000 & & 31,075 \\
Nguru & 162,770 & 139,765 & 48,000 & 39,435 & 46,600 \\
Potiskum & 356,540 & 156,000 & 49,000 & & 42,750 \\
Tarmuwa & 94,950 & 42,000 & 33,000 & & 22,840 \\
Yunusari & 57,670 & 27,815 & 27,000 & 21,645 & 23,450 \\
Yusufari & 54,650 & 24,115 & 24,000 & 17,875 & 19,670 \\
Mean & 121,450 & 58,741 & 33,000 & 28,064 & 28,737 \\
STD & 75,290 & 47,572 & 8551 & 6724 & 9465 \\
\hline Source: Fieldwo & $\mathbf{2 0} 2017$ & & & &
\end{tabular}

Source: Fieldwork 2017 during droughts, thus, exacerbates the impact of droughts on the environment and human comfort. Abaje et al. (2013) state that during drought periods, the land is under increased stress from both human beings and livestock, through unsustainable agricultural practices, leading to increasing desertification (Oyekale 2009; Eze et al. 2018). Mortimore et al. (2009) have shown that overgrazing becomes destructive during drought, when large areas that would normally have been available for grazing dry up, animals are forced to feed on any available edible vegetation they could find. This may be harsh enough to cause severe damage to the environment, particularly in the study area. Nyong et al. (2003) argue that once the unsafe balance of the plant communities adapted to the characteristically variable climate is upset by persistent drought, complete ecological recovery may be impossible, even when the rains return leading to severe desertification.

The increasing drought occurrences in the study area, therefore, have great implications for the household livelihoods. The occurrence of mild drought results in a reduction in crop yield and cattle weight loss, whereas the occurrence of severe drought results in total crop loss, in increased mortality rates of livestock (Abaje et al. 2013; Wu et al. 2015a, 2015b). The reduction in crop yield and livestock loss affects revenue generation and household income. Consequently, about $65 \%$ of the total respondents depends primarily on farming, thus increasing drought occurrences affects household revenue generation and food availability in the study area. Eze et al. (2018) argue that households whose livelihood depends on farming suffer losses during drought because the crop yield and livestock production are reduced and also, the weight and strength of cattle for the purpose of draught power is drastically reduced. Moreover, the frequent incidences of droughts resulted to the lowering of water table and sustenance of few rivers. Thus, developmental projects that depend on water from rivers and groundwater sources suffer a great setback during and after drought. The lowering of water table has a negative effect on the construction of wells and boreholes. This is because the depth of the water table increases, and may not be reached depending on a place, thus reducing water availability for the household uses, particularly those that depend on surface and groundwater sources. Therefore, dependency on agriculture increases the vulnerability of the households to drought. Moreover, persistent and substantial reduction in the provision of ecosystem services as a result of the incidence of droughts possesses great threats to agricultural productivity.

\section{Recommendations}

To address the impact of drought on households, food systems have to become more efficient and resilient (Eze et al. 2018). Moreover, climate-smart practices aim to improve food security, help communities adapt to 
Table 7 Analysis of variance of income of respondents from different occupations in Yobe state

\begin{tabular}{lllcrl}
\hline Source of Variation & Sum of Squares & Degree of Freedom (DF) & Mean Sum of Squares & F-ratio & P-Value \\
\hline Between Groups & $100,736,213,073$ & 4 & $25,184,053,268$ & 13.77243 \\
Within Groups & $129,829,514,017$ & 71 & $1,828,584,704$ & .00001 \\
Total & $230,565,727,090$ & 73 & & \\
\hline
\end{tabular}

Significant at 0.05 confidence level (Source: Fieldwork 2017)

drought and contribute to drought mitigation by adapting to appropriate practices, developing enabling policies and mobilizing needed finances. Therefore, we recommend the short and long-term measures to protect the households against the disaster and problems of drought through the following:

(i) Establishment of irrigation system: Irrigation system (Tube-well) will help households that are dependent on farming to cultivate and harvest crops during drought or shortfall in rainfall amount. This can be done by providing tube-well for every registered farmer in the state, by the government.

(ii) Use of improved crop varieties: Making early maturing and drought resistant crops available and affordable will enable farmers to cultivate and harvest crops within a short period, while droughtresistant crops should be able to survive and grow with little water available in the soil. The new improved crop varieties enhance the reduction of drought impacts on farmers.

(iii) Livelihood diversification: Government should create economic activities that will generate nonfarm employment to reduce the impact of drought on the households. These could be achieved through finance and technical assistance such as loans and capacity building. When finance and technical assistance are given to the households, it could motivate them to venture into small and medium scale businesses such as skill acquisition, (such as production of local briquettes, tailoring, cake making, trades and others, which on its own will generate employment

\section{Conclusion}

In conclusion, there are high incidences of drought in the study area. The frequent occurrence of droughts has impacted negatively on the environment and human comfort. However, the predominant households in the study area are highly dependent on agriculture. Consequently, agriculture is, however, currently being constrained by the frequent occurrence of drought, in the study area. Moreover, dependency on farming has contributed to the high level of households' vulnerability to drought in the study area. Thus, there is a need for integrated development schemes aimed at livelihood diversification and increasing the adaptive capacity of households to drought in the study area. Although the results of this study indicate the specific features of a State, future research should focus on a national level, which is highly aggregated. More capacity and work is needed particularly at the national level to assess the extent of drought and its impact on the households.

Finally, the study has successfully used Normalized Rainfall Index and Analysis of variance to determine the extent of drought occurrences and its implications on the households, which has much to offer in terms of policy decisions.

\section{Acknowledgements \\ I am sincerely indebted to my lecturers in the Department of Geography, University of Nigeria Nsukka, for exposing me to a wider range of knowledge, provided me with relevant materials and their helpful comments during my PhD programme. \\ Funding \\ This research was not supported by any government or non-governmental organization. It was self-sponsored and supported by family members.}

\section{Availability of data and materials}

The datasets used and analysed during the current study are available from the corresponding author. Thus, it can be made available on reasonable request.

\section{Author's contributions}

The whole research work (design of the study, data collection, analysis, interpretation and writing the manuscript) were carried out by the author alone. The author read and approved the final manuscript.

\section{Competing interests}

The author declares that he has no competing interests.

\section{Publisher's Note}

Springer Nature remains neutral with regard to jurisdictional claims in published maps and institutional affiliations.

Received: 30 June 2018 Accepted: 9 October 2018

Published online: 22 October 2018

\section{References}

Abaje, I.B., O.F. Ati, E.O. Iguisi, and G.G. Jidauna. 2013. Droughts in the SudanoSahelian Ecological Zone of Nigeria: Implications for Agriculture and Water Resources Development. Global Journal of Human Social Science 13 (2): 12-23. Anyadike, R.N.C. 1993. Seasonal and annual rainfall variations over Nigeria. International Journal of Climatology, 13: 567-580.

Ayoade, J.O. 1988. On Drought and Desertification in Nigeria. In Environmental Issues and Management in Nigerian Development, ed. P.O. Sada and F.O. Odemerho, 271-290. Ibadan: Evans Brothers (Nigerian Publishers) Limited.

Bates, B.C., Kundzewicz, Z.W., Wu, S.and Palutikof, J.P. (Eds). (2008). Climate Change and Water. Technical Paper of the Intergovernmental Panel on Climate Change, IPCC Secretariat, Geneva. Available from https://www.ipcc. 
ch/pdf/technical-papers/climate-change-water-en.pdf - 28/doc13.pdf (accessed: June, 2018).

Brazel, S.W., and R.C. Balling. 1986. Temporal analysis of long-term atmospheric moisture levels in Phoenix, Arizona. Journal of Climate and Applied Meteorology 25: 112-117.

Dai, A., P.J. Lamb, K.E. Trenberth, P. Hulme, D. Jones, and P. Xie. 2004. The recent Sahel drought is real. International Journal of Climatology 24: 1323-1331.

Eze, J.N. 2017. Assessment of Household Vulnerability and Adaptation to Desertification in Yobe State, Nigeria, A thesis submitted to the School of Postgraduate studies and the Department of Geography. Nsukka in Partial Fulfillment of the Requirements for the Degree of Doctor of Philosophy: University of Nigeria.

Eze, J.N., U. Aliyu, A. Alhaji-Baba, and M. Alfa. 2018. Analysis of farmers' vulnerability to climate change in Niger state, Nigeria. International Letters of Social and Humanistic Sciences. 82: 1-9.

Folland, C.K., Palmer, T., Parker D. 1986. Sahel rainfall and worldwide sea temperatures, 1901-85. Nature 320(6063):602-607. https://doi.org/10.1038/ 320602a0.

Gidey, E., O. Dikinya, R. Sebego, E. Segosebe, and A. Zenebe. 2018. Analysis of the long-term agricultural drought onset, cessation, duration, frequency, severity and spatial extent using vegetation health index $(\mathrm{VHI})$ in Raya and its environs, northern Ethiopia. Environmental Research System 7 (13). https://doi. org/10.1186/s40068-018-0115-z.

Hosseinizadeh, A., H. SeyedKaboli, H. Zareie, A. Akhondali, and B. Farjad. 2015. Impact of climate change on the severity, duration, and frequency of drought in a semi-arid Agricultural Basin. Geoenvironmental Disasters 2 (23). https://doi.org/10.1186/s40677-015-0031-8.

Khalil, I.M. 1974. North-eastern state report on long term measures to combat drought. Maiduguri: Government Printer.

LIU, Xianfeng, Xiufang ZHU, Yaozhong PAN, Jianjun BAl, and Shuangshuang LI. 2018. Performance of different drought indices for agriculture drought in the North China plain. Journal of Arid Land. https://doi.org/10.1007/s40333-0180005-2.

Mortimore, M., Anderson S., Cotula L., Davis J., Faccer S., Hesse C., Morton J., Nyangena W., Skinner J., and Wolfangel C. 2009. Dryland opportunities: A new paradigm for people, ecosystems and development. IUCN, Gland, Switzerland., IIED London, UK., UNDP/DDC, Nairobi, Kenya.

Mortimore, M.J. 1989. Adapting to drought: Farmers. In Famines and desertification in West Africa. Cambridge: Cambridge University Press.

Musa, H.D., and B. Shaib. 2010. Integrated remote sensing approach to desertification monitoring in the crop-rangeland area of Yobe State, Nigeria. Journal of Sustainable Development in Africa. 12 (5): 236-250.

National Population Commission. 2006. Data for National Planning and Development. Population by class-size of households. Abuja: National Population Commission. http://population.gov.ng/wp-content/themes/ expo18/documents/Pr\%20Vol\%209\%20Size\%20of\%20Household.zip.

Nwaka, G.I. 1991. Pedogenesis and Soil Resources. In Gadzama, N.M. et al. (eds). Arid Zone. Hydrology and water Resources. University of Maiduguri press. 235-262.

Nyong, A., A. Adepetu, V. Ihemegbulem, and D. Dabi. 2003. Vulnerability of rural households to drought in northern Nigeria. Assessment of impacts and adaptation to climate change (AIACC) Notes 2 (2): 6-7.

O'Connor, T.G. 1995. Transformation of a savanna grassland by drought and grazing. African Journal of Range and Forage Science. 12 (2): 53-60.

Oladipo, E.O. 1993. Some aspects of the spatial characteristics of drought in northern Nigeria. Natural Hazards. 8: 171-188.

Olagunju, T.E. 2015. Drought, desertification and the Nigerian environment: A review. Journal of Ecology and the Natural Environment 7 (7): 196-209.

Oyekale, A.S. 2009. Climatic variability and its impacts on agricultural income and households' welfare in southern and northern Nigeria. Electronic Journal of Environmental, Agricultural and Food Chemistry. 8 (7): 443-465.

Reid, P., and C. Vogel. 2008. Living and responding to multiple stressors in South Africa: Glimpses from Kwazulu-Natal. Global Environmental Change 16: 195-206.

Shiru, M.S., S. Shahid, N. Alias, and E.S. Chung. 2018. Trend analysis of droughts during crop growing seasons of Nigeria. Sustainability 10 (871): 1-13. https:// doi.org/10.3390/su10030871

Tarhule, A., and M.-K. Woo. 1997. Towards an interpretation of historical droughts in northern Nigeria. Climatic Change 37: 601-616.
Tiamiyu, S.A., J.N. Eze, T.M. Yusuf, A.T. Maji, and S.O. Bakare. 2015. Rainfall variability and its effect on yield of Rice in Nigeria. International Letters of Natural Sciences 49: 63-68.

Tschakert, P. 2007. Views from the vulnerable: Understanding climatic and other stressors in the Sahel. Global Environmental Change 17: 381-396.

Türkes, M. 1996. Meteorological drought in Turkey: A historical perspective, 1930. 93. Drought Network News 8 (3): 17-21.

Um, M., Y. Kim, D. Park, and J. Kim. 2017. Effects of different reference periods on drought index estimations from 1901 to 2014. Hydrology and Earth System Sciences 21: 4989-5007

Wu, Y., B. Bake, J. Zhang, and H. Rasulov. 2015b. Spatio-temporal patterns of drought in North Xinjiang, China, 1961-2012 based on meteorological drought index. Journal of Arid Land 7 (4): 527-543. https://doi.org/10.1007/ s40333-015-0125-X.

Wu, M. Y. Chen, H. Wang, and G. Sun. 2015a. Characteristics of meteorological disasters and their impacts on the agricultural ecosystems in the northwest of China: A case study in Xinjiang. Geoenvironmental Disasters20152: 3. https://doi.org/10.1186/s40677-015-0015-8.

Yamane, T. 1967. Statistics: An introductory analysis. 2nd ed. New York: Harper and Row.

Yue, Y., S. Shen, and Q. Wang. 2018. Trend and variability in droughts in Northeast China based on the reconnaissance drought index. Water 10 (318): 1-17.

\section{Submit your manuscript to a SpringerOpen ${ }^{\circ}$ journal and benefit from:}

- Convenient online submission

- Rigorous peer review

- Open access: articles freely available online

- High visibility within the field

- Retaining the copyright to your article

Submit your next manuscript at $\boldsymbol{\nabla}$ springeropen.com 